\title{
LOPHOZIA DIVERSILOBA HATT. (HEPATICAE; LOPHOZIACEAE) DISCOVERED IN CHINA
}

\author{
LOPHOZIA DIVERSILOBA HATT. (HEPATICAE; LOPHOZIACEAE) \\ НАЙДЕНА В КИТАЕ \\ JUN SUN ${ }^{1} \&$ TONG CAO ${ }^{1}$ \\ ЮН Сун ${ }^{1} \&$ ТОНГ ЧАО ${ }^{1}$
}

Abstract

\begin{abstract}
Lophozia diversiloba Hatt. previously known only from Japan, is reported from Sichuan Province, Southwest China. Description, illustration and ecology data of the species are provided. The systematic position of $L$. diversiloba is also discussed.
\end{abstract}

Резюме

Lophozia diversiloba Hatt. ранее была известна только из Японии. Сообщается о находке этого вида в провинции Сычуань, Юго-Западный Китай. Приводятся описание, иллюстрации и сведения о местообитании вида, а также обсуждается его систематическое положение.

According to Piippo (1990), Whittemore (1998) and Piippo \& al.(1998),22 species of the genus Lophozia are recongnized in China. During recent study of Chinese Lophoziaceae for Bryoflora of China, we examined three interesting specimens collected from Wulong Nature Reserve (the Reserve for protection of Panda!), Southwest China. They are identified as Lophozia diversiloba Hatt., which was previously known only from Japan and is reported new to China here.

Lophozia diversiloba Hatt., J. Jap. Bot. 20: 265. 1944. Type: «prov. Musasi, Hikawamati, in monte Tenso-zan, Tateiwa (S. Hattori no. 352)Typus, 6 Jul. 1949. m Herb. Mus. Sci. Tokyo.» (Holotype - TNS, not seen). Figs. 1-9.

Acrobolbus diversilobus (Hatt.) Hatt., J. Hattori Bot. Lab. 12: 76. 1954. Hattoriella diversilo$b a$ (Hatt.) Inoue, J. Hattori Bot. Lab. 23: 40. 1960.

Plants medium in size, creeping with ascending ti ps,yellow-green above,green-brown to dark-brown below, in dense mats. Stems 1-2 $\mathrm{cm}$ long, $1-1.5 \mathrm{~mm}$ wide with leaves, sparsely branched, about $0.12 \mathrm{~mm}$ thick, $12-14$ cells wide, cortical and medullary cells same, subqudrate, thin-walled, pellucid, 20-26 $\mu \mathrm{m}$. Rhizoids numerous and dense on ventral side of stem, up to $0.3 \mathrm{~cm}$ long. Leaves imbricate to contiguous, somewhat dorsally secund, spreading, obliquely inserted, shortly decurrent at base, round- subquadrate to short-rectangular 0.85-1.0 mm wide, 1.2-1.35 mm long, bilobed to 1/4-1/5 leaf length; lobes more or less unequal, triangle, acuminate, apices long, (2)3-5 cells high. Underleaves absent. Upper and apex leaf cells irregular-rounded, 23$30 \mu \mathrm{m}$; middle cells $26-32 \mu \mathrm{m}$; basal cells elongate, 24-26 $\mu \mathrm{m}$ wide, $40-50 \mu \mathrm{m}$ long; cells thinwalled, with large, distinct, yellowish trigones; cuticle faintly striate-verrucose; oil-bodies few, gray, 4-6 per cell, elliptical to subspherical, б-9 $\mu \mathrm{m}$ long, finely granular. Gemmae absent. Dioicous. Perianth nearly emergent, cylindrical to cylindrial-ovoid, plicated near contracted rounded mouth; mouth remotely crenulate, with projecting elongate cells. Female bracts a little larger than stem leaves, mostly 2-lobed, sometimes with 1-3 teeth along margins. Others not seen.

Distinguishing features: Lophozia diversiloba is characterized by having: (1) plants forming greenish brown mats with numerous yellowish color of ascending shoots apices; (2) Leaves more or less secund, round-subquadrate to rectangular, bilobed to about 1/4-1/5 the leaf length; (3) Lobes acuminate, apices long, (2)3-5 cells high; (4) Leaf cells with large, distinct trigones; cuticle faintly striateverrucose; (5) Perianth cylindrical to cylindricalovoid, plicated near the contracted rounded-mouth.

Chinese specimens examined: Sichuan Prov., Wulong Nature Reserve, Hero-valley, alt. 2300-2500 m, on wet or dry rocks, 23 Sept. 1992. Cao Tong 43072, 43079, 43123 (IFSBH).

1 - Institute of Applied Ecology, Academia Sinica, Shenyang, Liaoning 110016, China (correspondence to be sent to the latter author) 


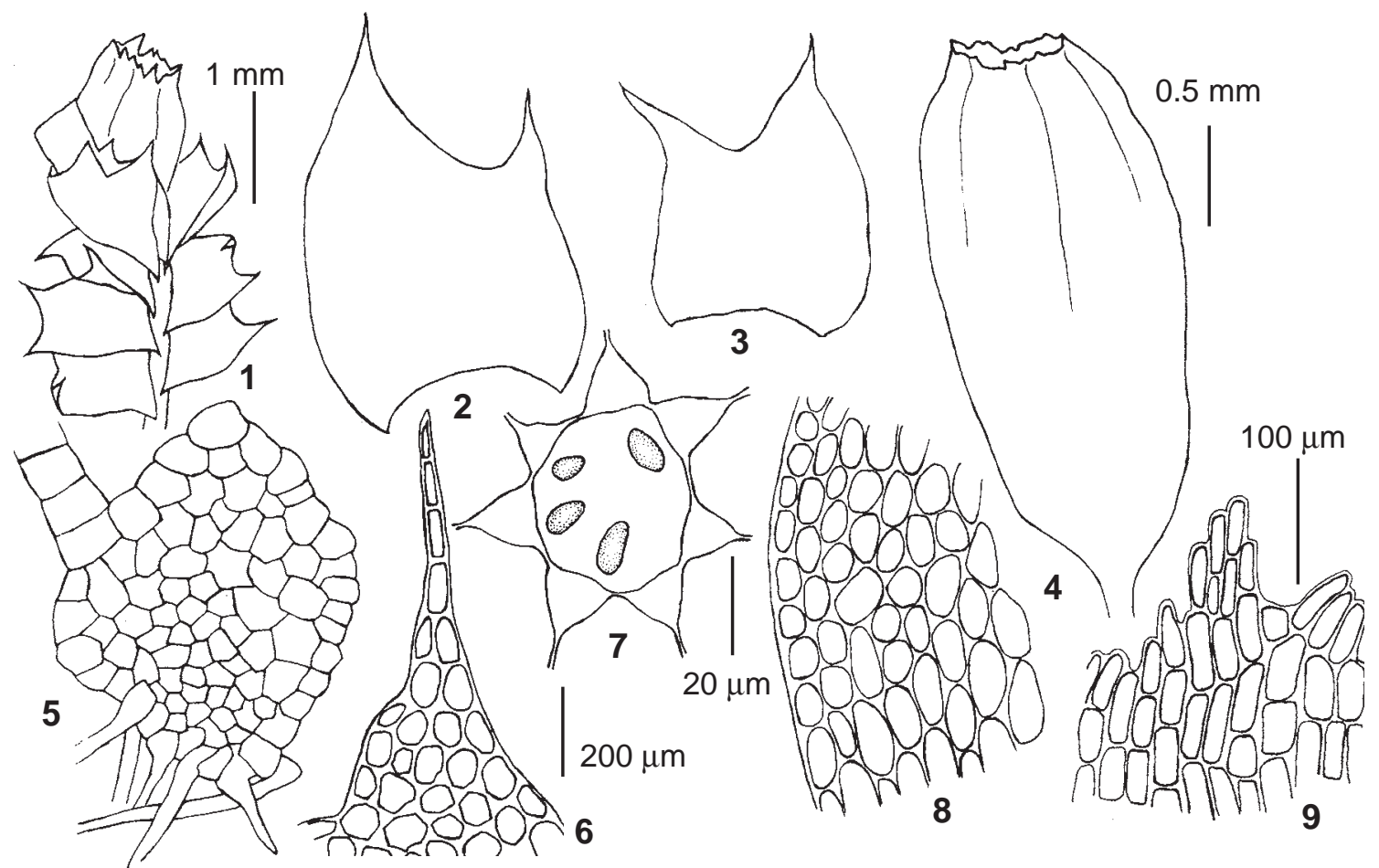

Figs. 1-9. Lophozia diversiloba Hatt. (drawn from Sichuan, Cao Tong 43123): 1 - part of plant with perianth; 2-3 - leaves; 4 - perianth; 5 - transverse section of stem; 6 - cells of leaf apex; 7 - middle leaf cell with oil-bodies; 8 - leaf base cells; 9 - perianth mouth cells. Scale bars: $1 \mathrm{~mm}$ for $1 ; 0.5 \mathrm{~mm}$ for 2-4;200 $\mu \mathrm{m}$ for $6 ; 100 \mu \mathrm{m}$ for 5,8 and $9 ; 20 \mu \mathrm{m}$ for 7 .

Habitat: Lophozia diversiloba is distributed in calcareous region and grows on bared and humid limestone or on thin layer soil covering limestone (Inoue 1957, Kitagawa 1966). The populations of $L$. diversiloba from Southwest China grow on thin layer soil covering calcareous stone with $\mathrm{pH} 7.45$ on mountain area at elevation of 2300-2500 $\mathrm{m}$ above sea level.

Distribution: L. diversiloba has been regarded as endemic species to Japan and recorded from Honshu and Shikoku (Mt. Tenso, Mt. Jumonji, Mt. Shiroiwa, Mt. Senjo, Mt. Shiomi, Mt. Tsurugi, Mt. Ishidate) (Hattori 1944; Inoue 1957,1960; Kitagawa 1966). Discovery of this species in China extends its distributional range and the species should be considered as the East Asian one.

The systematic position of L. diversiloba has been treated differently since its original description (Hattori, 1944). Hattori (1954) replaced the generic name to Acrobolbus based on the character of oilbodies. In 1957, when Inoue collected male plants and sporephytes, he proposed a new monotypic subgenus Hattoriella in the genus Lophozia by characters of perianth; sporophyte structure, oil-bodies, male bracts with paraphyllia and absent of gemmae etc. Later, Inoue (1960) established a new genus Hattoriella including $H$. diversiloba (Hatt.) Inoue and H. mayebarae (Hatt.) Inoue. Kitagawa (1966) treated it as Lophozia diversiloba. We agree with Kitagawa and considered it as a species of Lophozia.

\section{AKNOWLEDGMENTS}

The project was supported by Chinese Academy of Science (project: KZ952-J 1-022) and the National Nature Science Foundation of China.

\section{LITERATURE CITED}

HATTORI, S. 1944. Notulae de Hepaticis Japonicis IX. J. Jap. Bot. 20(5): 265-266.

HATTORI, S. 1954. Hepaticae Japonicae Exsiccatae Ser. 16. - J. Hattori Bot. Lab. 12: 76-90.

INOUE, H. 1957. Notes on the taxonomical status ofLophozia diversilobe. - Bot. Mag. Tokyo 70: 357-362.

INOUE, H. 1960. A new genus Hattoriella of the Lophoziaceae. - J. Hattori Bot. Lab. 23: 37-40.

KITAGAWA, N. 1966. A revision of the family Lophoziaceae of Japan and its adjacent region II. - J. Hattori Bot.
Lab. 29: 101-149.

PIIPPO, S. 1990. Annotated catalogue of Chinese Hepaticae and Anthoceratae. - J. Hattori Bot. Lab. 68: 1-192.

PIIPPO, S., X.-L. HE, T. KOPONEN, , P. J. REDFEARN \& J.- X. LI 1998. Hepaticae from Yunnan, China, with a checklist ofYunnan of Hepaticae and Anthoceratae. J. Hattori Bot. Lab. 84: 135-158.

WHiTTEMORE, A. T., ZHU, R.-L. \& R.-E. HU 1998. A checklist of liverworts ofXinjiang, China. - Bryologist 101(3): 439-443. 